\title{
QUESTÃo AGRÁRIA, PESQUISA E MST ${ }^{1}$
}

Fernando Dreissig de Moraes $^{2}$

Sabe-se que o conflito da luta pela terra não é recente. Existem vários movimentos sociais que lideram essa reivindicação, entre os quais, destaca-se o Movimento dos Trabalhadores Sem-Terra (MST). O autor Bernardo Mançano Fernandes, na presente obra, apresenta um panorama muito amplo acerca do MST ao abordar, em seus textos, temas contemporâneos da questão agrária, a contextualização geográfica dos movimentos sociais e metodologias de pesquisa sobre o assunto. Torna-se, portanto, fundamental sua leitura a todos aqueles que desejam aprofundar seus conhecimentos em torno dos movimentos sociais de luta pela terra (em especial, o MST).

Bernardo Fernandes tem longa experiência no estudo desse tema. É pesquisador do Núcleo de Estudos, Pesquisas e Projetos de Reforma Agrária (Nera) e há mais de 20 anos estuda o MST. Questão Agrária, Pesquisa e MST certamente quebra um paradigma de que a ciência deve ser absolutamente neutra, fato que o próprio autor deixa claro logo nas primeiras páginas.

A partir de agora, vejamos as questões mais pontuais desse livro, tentando deixar transparecer a opinião do autor, para que o leitor da presente resenha possa ter clara a idéia original da obra.

Questão Agrária, Pesquisa e MST desenvolve-se em três eixos: o primeiro, início do livro, discute temas pertinentes da questão agrária atual. O segundo, como o próprio autor afirma, é um "ensaio teórico", no qual existe uma análise muito mais epistemológica e, em certos momentos, simbólica do movimento, propondo o estudo dos processos de construção de territórios e espaços da luta pela terra.. O terceiro eixo explica as principais atividades de ensino, pesquisa e extensão realizadas com o MST, havendo após uma relação da demandas do Movimento quanto à pesquisa; finalizando, o autor faz um pequeno "manual" para pesquisadores iniciantes que desejam estudar o tema.

\footnotetext{
${ }^{1}$ Resenha elaborada para a disciplina Geografia Agrária, junto ao Departamento de Geografia da Universidade Federal do Rio Grande do Sul, durante o segundo semestre letivo de 2006

2 Aluno do curso de graduação em Geografia pela Universidade Federal do Rio Grande do Sul fernandodm87@yahoo.com.br
} 
$\mathrm{Na}$ apresentação da obra, o autor deixa claro o seu questionamento sobre a neutralidade da ciência e afirma que muitos pesquisadores consideram impossível desassociar a militância política da neutralidade científica. Fernandes considera, porém, que a neutralidade jamais é apolítica e que a militância é fruto da simpatia com determinadas organizações.

Ao discorrer sobre questões contemporâneas dos movimentos sociais, o autor lembra que a intensificação da luta se dá a partir da década de 70, devido às transformações impostas pelos governos militares. No entanto, ocorre no governo de Fernando Henrique Cardoso (1995-2002), uma tentativa de capitalização dos agricultores sem-terra, objetivando a incorporação desses pequenos agricultores à lógica do mercado, já que não houve muita dificuldade em realizar reforma agrária em seu mandato.

Os problemas relacionados à propriedade da terra são intrínsecos à estrutura fundiária, vindo daí os processos de expropriação, expulsão e exclusão que ocasionam os movimentos de resistência. A partir desse momento, inicia-se a batalha contra o capital, que se confunde com a luta pela terra. A política do Governo FHC consistia em promover um tipo de agricultura familiar que nada mais era que uma forma de inserção dos agricultores à lógica capitalista e, principalmente, uma estratégia para enfraquecer o movimento.

Bernardo Fernandes, nesse primeiro eixo da obra, também cita importantes referenciais teóricos, como as obras de Abramovay, Prado Júnior, Guimarães e Stedile.

O segundo eixo do livro trata da categorização geográfica do movimento social, no qual objetiva uma elucidação de conceitos e idéias aos geógrafos que pretendem se aprofundar em seu estudo. Para ele, a especificidade do movimentos é que eles "constroem estruturas, desenvolvem processos, organizam e dominam territórios da mais diversas formas" (FERNANDES, 2001, p. 50).

O estudo dos movimentos sociais de luta pela terra é categoria recente, havendo, portanto, necessidade de elaborar pesquisas sobre os processos de territorialização presentes. E essa categoria abrange diferentes esferas do estudo geográfico: social, político, econômico, entre outros. Para ele, o processo de ocupação é oriundo da territorialização e da espacialização, que criam a experiência de resistência dos sem-terra.

Ao estabelecer o exercício de descrição, Fernandes estabelece uma espécie de "metodologia de ocupação", no qual discorre sobre as etapas desse processo de formação de territórios, que mudam a conjuntura espacial dos locais em que o assentamentos ou 
acampamentos ocorrem. Esses processos de espacialização são muito dinâmicos e heterogêneos.

No terceiro e último eixo do livro, o autor discorrer sobre a pesquisa acerca do MST. Nele, Fernandes realiza um breve histórico sobre a pesquisa a respeito do MST; algumas linhas de pesquisa já consolidadas, além da importância das diversas áreas do conhecimento para o estudo do Movimento. No final, faz uma proposta para a escolha de temas para a pesquisa. O autor apresenta a chamada "Agenda de Pesquisa do Movimento dos Trabalhadores Rurais Sem-Terra", no qual é feita uma tabela com vários temas para pesquisa em temas como educação, direito, organização do MST, desenvolvimento humano, história e geografia camponesa e cultura.

Finalizando, o autor descreve os principais passos para elaborar um projeto de pesquisa, no qual justifica pelo fato de os pesquisadores iniciantes terem muitas dúvidas e dificuldades para fazê-lo.

Questão Agrária, Pesquisa e MST é uma leitura recomendada a todos aqueles que desejam ingressar na pesquisa sobre conflitos e luta pela terra, ao mesmo tempo em que interessa ao público em geral, mesmo àqueles que não estão ligados à Geografia, já que uma obra de fácil entendimento, já que o autor usa uma linguagem muito clara, fugindo de termos extremamente imbricados de acordo com a linguagem acadêmica.. Bernardo Fernandes conseguiu explicitar claramente suas idéias nesse texto, deixando clara a sua crença na nãoneutralidade da ciência.

Em questão à aparência estética, a obra possui formato muito agradável de leitura, já que pode ser considerada como um "livro de bolso". O autor conseguiu expor sua idéia em poucas páginas, o que torna a leitura mais fácil e, logicamente, rápida. Utilização semântica das palavras é apropriada; o texto não apresenta erros claros de gramática, grafia ou acentuação. Infelizmente, o autor não utiliza uma importante ferramenta da Geografia: a Cartografia Temática. Não há mapas ou gráficos que ilustrem alguns dados passados por Fernandes.

Após a leitura do texto, faz-se imprescindível uma análise da questão agrária no Brasil. Pôde-se perceber o tratamento do assunto dado pelo governo vigente na época (gestão do ex-presidente Fernando Henrique Cardoso), que preconizava a inserção do pequeno agricultor à lógica capitalista de mercado. A reflexão acerca do assunto é válida, já que, após mais de cinco anos, a situação dos agricultores sem-terra continua a mesma, não havendo por parte do governo uma iniciativa efetiva para transformar essa realidade. Somente no momento 
em que houver a reforma agrária e políticas que possibilitem a sustentabilidade do pequeno agricultor, o conflito pela terra poderá ser reduzido.

\section{REFERÊNCIA:}

FERNANDES, Bernardo Mançano. Questão Agrária, pesquisa e MST. São Paulo: Cortez Editora, 2001 